\title{
The Significance of the Táin in the Promotion of Cultural Nationalism with Particular Reference to Two Musical Compositions Inspired by Thomas Kinsella's 1969 Translation
}

De l'importance du Táin pour la promotion du nationalisme culturel : le cas de deux compositions musicales inspirées par la traduction de Thomas Kinsella (1969)

\section{Angela Horgan Goff}

\section{(2) OpenEdition}

Journals

Electronic version

URL: https://journals.openedition.org/etudesirlandaises/11947

DOI: 10.4000/etudesirlandaises. 11947

ISSN: 2259-8863

\section{Publisher}

Presses universitaires de Caen

\section{Printed version}

Date of publication: 30 December 2021

Number of pages: $103-118$

ISBN: 978-2-84133-157-0

ISSN: 0183-973X

Electronic reference

Angela Horgan Goff, "The Significance of the Táin in the Promotion of Cultural Nationalism with Particular Reference to Two Musical Compositions Inspired by Thomas Kinsella's 1969 Translation", Études irlandaises [Online], 46-2 | 2021, Online since 17 December 2021, connection on 05 November 2022. URL: http://journals.openedition.org/etudesirlandaises/11947 ; DOI: https://doi.org/10.4000/ etudesirlandaises. 11947

\section{(c) (i) (2)(2)}

Creative Commons - Attribution-NonCommercial-ShareAlike 4.0 International - CC BY-NC-SA 4.0 https://creativecommons.org/licenses/by-nc-sa/4.0/ 


\title{
The Significance of the Táin in the Promotion of Cultural Nationalism with Particular Reference to Two Musical Compositions Inspired by Thomas Kinsella's 1969 Translation
}

\begin{abstract}
This interdisciplinary discussion explores cultural nationalism across the creative arts in relation to the significance of the ancient saga, the Táin. Thomas Kinsella's 1969 translation of Táin Bó Cuailnge [Brown Bull of Cooley] has proved to be a key post-Revival literary source from the ancient manuscripts of Ireland, as it has prompted renewed interest in the saga. Various creative artists have engaged with the Táin as a result of this translation, thereby contributing to a novel movement toward Irish cultural nationalism. The paper compares two Táin-inspired compositions by James Wilson and Aloys Fleischmann as each composer's musical language yields insight into prevailing attitudes in Irish society towards the end of the $20^{\text {th }}$ century.
\end{abstract}

Keywords: cultural nationalism, Thomas Kinsella, Táin, Irish literature, Irish traditional music, Aloys Fleischmann, James Wilson.

Résumé: Cet article propose une analyse pluridisciplinaire du nationalisme culturel irlandais à travers une étude du récit épique, Táin. La traduction de Thomas Kinsella de Táin Bó Cuailnge [La rafle des vaches de Cooley] (1969) a facilité l'accès aux anciens manuscrits irlandais et suscité un regain d'intérêt pour la saga. Nombre d'artistes se sont inspirés de la Táin grâce à cette traduction et ont contribué à une nouvelle forme de nationalisme culturel en Irlande. L'article compare deux compositions musicales inspirées de la Táin, l'une de James Wilson, l'autre d'Aloys Fleischmann, et montre que le langage musical des deux compositeurs jette un éclairage intéressant sur la société irlandaise de la fin du XXe siècle.

Mots clés: nationalisme culturel, Thomas Kinsella, Táin, littérature irlandaise, musique traditionnelle irlandaise, Aloys Fleischmann, James Wilson.

This interdisciplinary discussion explores cultural nationalism across the creative arts in relation to the significance of the ancient saga, the Táin, and focuses on two musical compositions inspired by Thomas Kinsella's, The Tain; ${ }^{1}$ a monodrama by James Wilson (1922-2005) and a three-act ballet by Aloys Fleischmann (1910-1992).

1. To distinguish between references to the ancient saga and Kinsella's translation, the author adheres to the Táin and The Tain respectively. Although later editions of Kinsella's translation of The Tain include a fada on the 'a', the author refers to the 1970 Oxford University Press edition which omits the fada (Thomas Kinsella, The Tain from the Irish Epic Táin Bó Cuailnge [1969], Oxford, Oxford University Press, 1970). 
Kinsella's 1969 translation of the Táin Bó Cuailnge [Brown Bull of Cooley] has proved to be a major post-Revival literary source from the ancient manuscripts of Ireland as it has prompted renewed interest in this epic from the Ulster Cycle. ${ }^{2}$ Various artists, primarily literary, but also visual and musical, have engaged with the saga and therefore contributed to a movement of Irish cultural nationalism. It is worth comparing the two Táin-inspired works by Wilson and Fleischmann as despite both composers being born abroad they were eager to forge a cultural link with their new homeland. An exploration of each composer's musical language yields insight into the prevailing attitudes in Irish society towards the end of the $20^{\text {th }}$ century, including lingering influences of nationalism as well as modernism. A brief discussion on cultural nationalism precedes contextual backgrounds to the cultural significance of the Táin, and Kinsella's translation. Subsequently, cultural perspectives are offered on the respective compositional languages employed by Wilson and Fleischmann in the two Táin-inspired works.

\section{Cultural nationalism}

Nationalism is a complex and controversial phenomenon that has engendered much debate in historical, political, sociological and cultural studies. There exists an extensive literature pertaining to political and cultural nationalism with notable examples written by Isaiah Berlin, Ernest Gellner and Elie Kedourie. Of interest is that these scholars present opposing views with regard to the evolution of nationalist ideas. Kedourie states that the phenomenon is "an ideological accident" as it "is a doctrine invented in Europe at the beginning of the $19^{\text {th }}$ century". ${ }^{3}$ In contrast, Gellner believes that nationalism is a natural outgrowth of the Romantic ideal which "valued and praised feeling and specificity, above all, cultural specificity as opposed to the rationalism and human universality of the Enlightenment". ${ }^{4}$ In coming to this realisation, Gellner draws on the Prussian philosopher Johan Gottfried Herder's message "that humanity was composed of nations / cultures, and their essence and value lay precisely in their specificity". ${ }^{5}$ Across the globe, numerous artists have embraced the "specificity" of their cultural past in the hope of maintaining, or indeed of creating, a cultural identity. In Ireland, the compulsion to preserve, revive and construct a national identity emanates from centuries of external cultural control, such as Viking invasions and British colonial domination.

While nationalism has led to some of the most severe atrocities perpetrated by mankind in the last century, it has also been a positive and productive force. Benedict

2. The Ulster Cycle comprises a large body of tales which are thought to be set in the first century before the birth of Christ and relate to the heroic adventures of the Ulaid - a pre-historic people who lived in the north-east of Ireland and from whom the modern name Ulster originates.

3. Elie Kedourie, Nationalism, $4^{\text {th }}$ ed., Oxford, Blackwell, 1993, p. 1.

4. Ernest Gellner, Nationalism, London, Weidenfeld and Nicolson, 1997, p. 67.

5. Ibid., p. 68. 
Anderson in his Imagined Communities: Reflections on the Origin and Spread of Nationalism (1983) states that "nation-ness is the most universally legitimate value in the political life of our time". He credits this "reality" with the fact that "since World War II every successful revolution has defined itself in national terms", such as the People's Republic of China and the Socialist Republic of Vietnam, and therefore "has grounded itself firmly in a territorial and social space inherited from the prerevolutionary [sic] past". ${ }^{6}$ Ireland also adheres to the legitimacy of Anderson's "nation-ness" as the country, for the greater part of the $20^{\text {th }}$ century, has been striving to create and maintain a strong national identity. ${ }^{7}$

Cultural nationalism is a form nationalism which focuses on national identity that is shaped by shared cultural traditions and a common language. Since Ireland gained independence from Great Britain in 1922, there has been much controversy over how best to establish an Irish identity; particularly across the creative arts. Leading up to the time of Kinsella's translation, the ideology of nationalism came into disrepute. The result of T. K. Whittaker's foreign investment policies, introduced in the 1950s, brought unprecedented economic growth, which gave some viable hope that the republic could economically sustain a united Ireland. The idea of a united Ireland, however, was not entertained by the homogenous Protestant community in Northern Ireland. The resulting social and political friction led to the escalation of the Troubles in Northern Ireland and culminated in Irish revisionist historians' repudiation of any sense of nationalism. They sought to erode cherished nationalist ideals and values considering them to be anachronistic. In addition, the economic boom saw a gradual shift to a more urbanised society and the insular form of protective nationalism was relegated to the margins of Irish politics. In joining the European Economic Community in 1974 (EEC, now European Union, EU) the government showed signs of looking beyond Ireland in the hope of establishing a modern independent society.

On the other hand, a heightened sense of nostalgia emerged during the straitened economic circumstances of the 1980s, as exemplified by the Bank of Ireland's use of Newgrange in an advertising campaign, the prominent rise of Celtic rock bands and the use of Celtic designs in jewellery and graphic art. These invocations of a pagan past could have been a reaction to the tight hold the Catholic Church had on Ireland at the time and may also have served as an authentic mode of expression that counteracted with the explosion of youth culture that had emerged in the 1960s and 1970s. Engaging with these ancient themes appears to be an attempt to create an aura of permanence, in a traditional sense, as opposed to any vestigial ideology. The economic boom of the 1990s, referred to as the Celtic Tiger, in addition to the

6. Benedict Anderson, Imagined Communities: Reflections on the Origin and Spread of Nationalism, London, Verso, 1983, p. 12-13.

7. The Anglo-Irish Agreement took place in December 1921 resulting in the establishment of the Irish Free State in 1922. The country was referred to as Éire from 1937 and became known as the Republic of Ireland on 18 April 1949. 
Peace Process, ${ }^{8}$ meant that Ireland witnessed further social and cultural changes. A new self-confidence emerged, and with it an increased acceptance of a pluralistic culture, as Ireland became part of the global economy.

Ireland slowly gained international recognition, and, similar to most Western cultures, entered the $21^{\text {st }}$ century as a pluralist society. This cultural diversity of different ideas makes the creation of a sense of "Irishness" all the more complex. ${ }^{9}$ Of interest here is the fact that from the late 1960s numerous creative artists sought to embrace Irish culture by engaging with the literary corpus of ancient sagas, and in particular the Táin, which is an integral part of Irish historical and cultural life. According to the Irish historian and philologist, Myles Dillon, these early manuscripts "are miniature libraries" as they include:

[...] legend, history and hagiography, bardic poetry and lyric poetry, medical and legal tracts, Old, Middle, and Modern Irish side by side. ${ }^{10}$

Renewed interest in the Táin in the late $20^{\text {th }}$ century may contribute to a deeper connection with the past and/or to an understanding of the present through an ancient motif. This is all the more apt considering that the last surge of musical interest in early Irish saga-literature occurred during the opening decades of Ireland's independence (1922-1942) when the revival and preservation of Ireland's culture was at the forefront. The Táin conveys a definite cultural influence across the creative art forms and therefore creates a link to a pre-seated tradition that resonates with contemporary Irish audiences.

\section{Cultural significance of the Táin}

The Táin has a long history which dates back as far as the $11^{\text {th }}$ century. ${ }^{11}$ Renewed interest in the saga appears to have been inspired by the Celtic Revival, during the closing decades of the $19^{\text {th }}$ century, and again following Kinsella's translation (1969). During the Celtic Revival artists and writers fused their work with the Gaelic literature of their past. ${ }^{12}$ This movement complemented the concurrent

8. The Peace Process involved the Irish government gaining access, for the first time, in parliamentary talks regarding the on-going Troubles in Northern Ireland.

9. The term "Irishness" relates to feelings associated with being Irish, which vary across a variety of disciplines. For further reading on numerous perspectives regarding what "Being Irish" means to people including a previous Taoiseach (Prime Minister), Bertie Ahern, artist Louis le Brocquy and historian Joseph Lee, see Being Irish: Personal Reflections on Being Irish Today, Paddy Logue (ed.), Dublin, Oak Tree, 2000.

10. Myles Dillon, Early Irish Literature, Dublin, Four Courts Press, 1997, p. xvii.

11. Excerpts of the Táin can be traced back to the $11^{\text {th }}$ century The Book of Dun Cow (Lebor na hUidre, $L U$ ), the $12^{\text {th }}$ century Book of Leinster (Lebor Núachongbála, $L L$ ), and the $14^{\text {th }}$ or early $15^{\text {th }}$ century Yellow Book of Lecan (YBL). LU: Royal Irish Academy, Dublin, MS 23 E 25; LL: Trinity College, Dublin, MS H 2.18; and YBL: Trinity College, Dublin, MS 1318.

12. The author acknowledges the complexity of Celticism in that it is more inclusive and cosmopolitan than the exclusive Gaelic tradition. This paper focuses on the historical influences of late $19^{\text {th }}$ and 
pan-European ideal of romantic cultural nationalism where artistic works embraced national identity. One of the earliest works based on a character from the ancient manuscripts of the Táin was by the Irish sculptor, Oliver Sheppard, whose The Training of Cúchulainn (1897) depicts a youthful figure being educated in warfare. Celtic revivalist interest in Cú Chulainn is also evident in the collections of stories Cuchulain of Muirthemne (1902) and Gods and Fighting Men (1904) translated by Lady Gregory who was an avid supporter of the Irish Literary Revival. Other writers including W. B. Yeats and George Russell appear to have inspired Sheppard's later bronze masterpiece The Death of Cuchulainn (1911) ${ }^{13}$ in that the sculptor transforms the character into a heroic ideal.

Sheppard, having studied in London and Paris, portrays The Death of Cuchulainn as a male nude which reveals a naturalistic modelling style (which bears a striking resemblance to images of the dead Christ) representative of the French sculptural technique associated with Auguste Rodin (1840-1917) and Jules Dalou (1838-1902). Despite Sheppard's work not being intended for political reference, The Death of Cuchulainn was later appropriated by Éamon de Valera (1935) and installed in the window of the reconstructed General Post Office, Dublin, to commemorate the $20^{\text {th }}$ anniversary of the 1916 Easter Rising. The significance of this symbolism is that the 1916 martyrs fought for Ireland's freedom against British rule which is a part of Irish history that is ingrained in Irish consciousness. This political reference also serves to emphasise the importance of the saga in the manifestation of cultural and social ideologies. For Sheppard however, the portrayal of a heroic male nude, based on myth, adhered to the practices of European sculpture of the time and is an example of how artists fused modern techniques with ancient Irish literature.

Although Sheppard's The Death of Cuchulainn (1911) exhibits contemporary French sculptural conventions of the time, almost sixty years later, the eminent Irish painter, Louis le Brocquy, who created the formal design of Kinsella's The Tain, captures the visual treatment of the saga through retrospective French influences. The content of le Brocquy's art predominantly focuses on Irish themes, however his visual treatment of the saga employs a blot technique that complements the text without competing with it. Le Brocquy looks beyond the local and specific Irish influences as his style and form reflect strong French influences, such as the particular attention he pays to the spatial considerations of the page; a concept initiated by the French symbolist poet Stéphane Mallarmé (1842-1898). ${ }^{14}$ Dolmen Press produced two versions of The Tain in 1969 comprising 1,700 copies of the first edition and only fifty of the deluxe second copy; both editions feature a detailed colophon giving the publications the hallmark of the livre d'artiste. Le Brocquy's drawings demonstrate

early $20^{\text {th }}$-century Celticism as opposed to the more commodity-focused and internationalist aspect of the topic.

13. Sheppard, Russell, and Yeats had studied together at the Dublin Metropolitan School of Art (1885-1887). For further reading on Sheppard's work, see John Turpin, "Portraits of Irish Patriots by Oliver Sheppard, 1865-1941”, Eire-Ireland, vol. 30, no. 4, 1995, p. 134-153.

14. These French influences are reminiscent of artists, such as Georges Rouault and Pierre Bonnard who have illustrated some of the finest livres d'artiste. 
the aesthetic values of the saga and parallels them with the livre d'artiste. ${ }^{15}$ In the Dolmen editions of The Tain, le Brocquy treats the page as an aesthetic element and he presents 136 ink drawings that feature within, and throughout, the text, both in the margins and as full plate illustrations. ${ }^{16}$ In comparison, the illustrations of the more widely available 1970 Oxford University Press paperback publication serve a merely decorative purpose, in that they are limited to 33 ink drawings, predominantly displayed as full plates or at the beginning and / or ending of a chapter. Le Brocquy's aim was to provide an extension of the words, stating that these drawings "derive their substance" as "shadows thrown by the text", ${ }^{17}$ suggesting deep engagement with the saga on the part of the painter in exemplifying its considered cultural meaning.

Despite the internationally acclaimed Irish sculptor, John Behan (b. 1938), having a lifelong appreciation for the Táin, he credits “Thomas Kinsella's magnificent re-creation, with Le Brocquy's illustrations" as having established the saga "in our memories and in our imaginations for ever". Behan's contribution to this "continuing artistic process" 18 is that his large-scale welded steel figures of various characters from the Táin, such as Cú Chulainn on a chariot, and Fer Diad with a bull, have been a welcome feature in the apt location of Dundalk town since the 1970s. The geographic locale of the saga has also been embraced by Ann Meldon Hugh who installed a statue of a devastated Cú Chulainn carrying the slain Ferdia, in Ardee, Co. Louth, where the Cooley Mountains serve as a backdrop to her artistic creation.

Since the publication of Kinsella's translation in 1969, ten Irish composers have engaged with various characters from the saga. ${ }^{19}$ The popular music genre also draws on the Táin as a source of inspiration; for example the Irish rock band Horslips released an LP in 1973 entitled "The Tain", ${ }^{20}$ while the folk punk group, The Pogues, feature "The Sickbed of Cuchulainn" on two albums, "Rum, Sodomy and the Lash" and "The Rest of the Best". ${ }^{21}$ The emergence of Celtic rock/punk

15. For further reading see Ailbhe Ní Bhriain, “Le Livre d'Artiste': Louis le Brocquy and 'The Tain' (1969)”, New Hibernia Review / Iris Éreannach Nua, vol. 5, no. 1, 2000, p. 69.

16. Ailbhe Ní Bhriain, “'Le Livre d'Artiste'...”, p. 73. See also p. 68-82 for interpretations of some of the drawings.

17. Thomas Kinsella, The Tain..., p. viii.

18. Brian Harten, "Quest for the Táin: An Exhibition by John Behan”, 5 March 2012, online: https:// www.createlouth.ie/quest-for-the-tain-an-exhibition-by-john-behan-r-h-a.

19. An Irish composer is recognised as "anyone who was born or is permanently resident in the Republic of Ireland or Northern Ireland". This is the official definition on the Contemporary Music Centre (CMC) website (Ireland's national archive and resource centre for new music), https://www.cmc.ie/composers. Further information on all studied composers is available at https://www.cmc.ie. For further reading on works inspired by the Táin, or sagas from the Ulster Cycle, see Angela Horgan Goff, “The Ulster Cycle: Cultural Significance for Irish Composers”, Estudios Irlandeses, vol. 12, no. 2, 2017, special issue, New Perspectives on Irish Folklore, p. 47-61.

20. “The Tain” was commercially released by RAC (UK: 1973), Atco (USA: 1973) and DJM (UK: 1978). The songs on this album reveal the story of the tale from the perspective of the characters such as "Ferdia's Song”, "Cú Chulainn's Lament” and "Dearg Doom”. Instrumental tracks include "Setanta" (which is Cú Chulainn's childhood name), "Maeve’s Court" and "The Morrigan's Dream".

21. "Rum, Sodomy and the Lash" (London: 1985, 2005) and "The Rest of the Best" (Ireland: 1992) were commercially released by WEA International. 
bands since the late 1960s has seen a rise in the fusion of rock music with Celtic music (hybrid of Irish, Scottish Gaelic, Welsh and Breton), instrumentation and themes that has contributed to a pan-Celtic culture. ${ }^{22}$ The Decemberists, who are an American Indie rock group, also released an album entitled "The Tain" with an accompanying video that comprises silhouettes and captions relating to the saga in the manner of a silent movie. ${ }^{23}$ In addition, it is worth noting that several popular and traditional music groups incur such titles as "The Cuchulainn Irish Ceili Band" and "The Cuchulainn Ceilidh Barn Dance Band".

In more recent times the artistic process of the Táin has continued, for example, through a number of graphic novels. The saga has re-emerged in the Irish language in a graphic novel entitled An Táin (2006), written by the prize-winning author Colmán Ó Raghallaigh and illustrated by Barry Reynolds. ${ }^{24}$ Cork artist / writer, Will Sliney, whose graphic novel, Celtic Warrior: The Legend of Cú Chulainn (2013), ${ }^{25}$ has subsequently gained international recognition through “The Amazing Spider-Man" (2014) illustrations for comic book giant Marvel. Clár Ní Dhuibheannaigh notes that Sliney's Cú Chulainn drawings are "imbued with a more personal inspiration" than his Marvel works as they "have a distinctly Irish flavour; enhanced by his incorporation of Oghamic inscriptions, and spiral carvings on standing stones". ${ }^{26}$ This fusion of ancient themes with modern media serves to highlight the cultural impact of the saga in that it has become immersed in the fashionable and hugely popular youth culture. The saga has continued to provide a timeless source of inspiration more than 900 years after it was first notated in The Book of Dun Cow; however it is Kinsella's translation which is of relevance here.

\section{Thomas Kinsella's The Tain (1969)}

Thomas Kinsella's translation of the Táin is the first complete and readable version, from the earliest form of the saga, in the English language. ${ }^{27}$ Kinsella focuses mainly on the earliest extant version of the epic, from The Book of Dun Cow, as he sought to "give an idea of the simple force of the story at its best". ${ }^{28}$ The text in this manuscript is incomplete, resulting in reference being made to another partial version of the saga in the later Yellow Book of Lecan. Kinsella also includes

22. Celtic rock bands have also played a major role in showcasing not only regional and national identities but have also created derivatives through further infusions such as blues.

23. The video of "The Tain" proceeds independently of the music as the lyrics of the songs bear no relevance to the tale apart from the third section of five in the title track entitled "The Tain". This EP was released by Acuarela Discos (Spain: 2004) and by Kill Rock Stars (USA: 2005).

24. Colmán Ó Raghallaigh, An Táin, Mayo, Cló Mhaigh Eo Book Publishers, 2006.

25. Will Sliney, Celtic Warrior: The Legend of Cú Chulainn, Dublin, O’Brien Press, 2013.

26. Clár Ní Dhuibheannaigh, "Legends and Superheroes", Irish Arts Review, vol. 31, no. 3, 2014, p. 78.

27. The first partial English translation from the earliest source was by L. Winifred Faraday, The CattleRaid of Cualnge, London, Nutt Publishers, 1904.

28. Thomas Kinsella, The Tain..., p. ix. 
one event from the Book of Leinster, this being the only version that explains the reason behind Medb's desire to capture the Brown Bull of Cooley. Despite the saga comprising a mix of prose and poetry, Kinsella maintains its episodic structure. At the time of publication, critics noted that the choice of language in Kinsella's composite text was both "harsh and simple" and that it seemed "perfectly in tune with the bloody, heroic world of Ireland's Iliad", ${ }^{29}$ suggesting parity with cultural and national influences.

Kinsella's engagement with the Táin may evidence his attempt to bridge the temporal gap which separates the contemporary reader from Ireland's cultural past. His embracing of the past instilled in him a strong sense of Irish identity and history in that he acknowledges, and strives to come to terms with, his relationship with the dual inheritance of Gaelic and English literature. He is acutely aware of the "divided mind", stating that modern Irish poets, including himself, are "unlikely to feel at home" in the English language. Looking beyond the poetic silence of the $19^{\text {th }}$ century he avers that there is "a great cultural blur" in that he "must exchange one language for another, my native English for eighteenth-century Irish". In this he recognises "a great inheritance and, simultaneously, a great loss". ${ }^{30}$ Despite sensing his own alienation from the Gaelic tradition, he is aware that Ireland's ancient literature provides a deep-rooted link with the past, which can be transformed into the present through the use of the English language. His translations have been praised for their sensitive rendering of Irish assonance, rhythm, and vocabulary, and they have enabled him to become familiar with this ancient Irish culture. ${ }^{31}$ For Kinsella, The Tain was to be "a living version of the story, leaving as few obstacles as possible between the original and the reader". ${ }^{32}$ In this sense, the ancient Irish language comes alive and provides a deep cultural experience for the contemporary reader.

Depending on the focus of the reader, the epic content of the Táin may be considered a romantic, or tragic, narrative. The main part of the Táin tells of how Queen Medb of Connacht aims to steal the valuable Brown Bull of Cooley in order to surpass her husband's wealth. Her jealous greed results in her declaring war on the men of Ulster, who are afflicted by an ancient debilitating curse, thus the defence of the province is left to the seventeen-year-old Cú Chulainn who kills all who dare to challenge him. ${ }^{33}$ A three-day duel between the heroic warrior

29. Unidentified correspondent, "Book of the Day - Recent Paperbacks - 2", The Irish Times, 27 November 1970, p. 12.

30. Thomas Kinsella, "The Divided Mind", in Irish Poets in English: The Thomas Davis Lectures on Anglo-Irish Poetry, Seán Lucy (ed.), Dublin, Mercier Press, 1973, p. 209.

31. Kinsella's translations include The Tain (1969, 1970), and An Duanaire 1600-1900: Poems of the Dispossessed (1981). He is both editor and translator of The New Oxford Book of Irish Verse (1986).

32. Thomas Kinsella, The Tain..., p. vii.

33. The Goddess Macha imposed this curse when she was forced by the King of Ulster to race against a chariot when she was heavily pregnant. She immediately gave birth to twins and screamed out that the men who heard her pain would suffer that agony for nine days in their times of great need. Kinsella's translation includes this story as a pre-tale "The Pangs of Ulster". See Thomas Kinsella, The Tain..., p. 6-8. 
and Fer Diad (Cú Chulainn's best friend and foster brother) leaves Cú Chulainn devastated as he eventually kills Fer Diad with his gae bolga; ${ }^{34}$ Medb and all her forces succumb to defeat. Cú Chulainn's god-like heroic status has been referred to as the "Irish Achilles" ${ }^{35}$ and this idealisation of a mythical hero typically features in the romantic category of Northrop Frye's taxonomy of narratives. ${ }^{36}$ A tragic mythos may also be considered if the reader heeds the catastrophic results that emerge from Medb's greed in wanting to capture the Brown Bull of Cooley. In addition, the identification of local features in the saga gives a sense of place and identity to Irish people, and the universal themes of either triumph or tragedy are relevant to daily life.

The trajectories of the two saga-based musical compositions by Wilson and Fleischmann reveal opposing mythoi, despite the works bearing the same title - The Táin. The libretto of Wilson's monodrama focuses on a tragic mythos whereby Cú Chulainn's killing of Fer Diad unfolds as the emotional peak of the monodrama. In contrast, the scenario of Fleischmann's ballet adheres to a romantic, or heroic, plot with Cú Chulainn emerging as the triumphant protagonist. ${ }^{37}$ The exploits of Cú Chulainn also feature in the works of four other Irish composers, all of which were written after Kinsella's translation. ${ }^{38}$ The works by Wilson and Fleischmann, however, are worth looking at as neither composer was born in Ireland, and, partly, through Irish texts, they strove to create and sustain a $20^{\text {th }}$-century construction of identity for themselves. ${ }^{39}$ In addition, they are the only composers who focused on a complete portrayal of the Táin, and their engagement with the saga reflects prevailing cultural perspectives in Irish society at the turn of the $21^{\text {st }}$ century.

34. A vicious weapon unique to Cú Chulainn, the gae bolga is said to be made from sea-monster bone and opens into barbs when it enters a body. It was given to Cú Chulainn by his female martial arts tutor, Scáthach.

35. Carroll L. Riley, “The Táin by Thomas Kinsella; Táin Bó Cuailnge”, American Anthropologist, New Series, vol. 72, no. 5, 1970, p. 1149.

36. For further reading on Frye's taxonomy of narratives see in particular the third essay entitled "Archetypal Criticism: Theory of Myths", in Northrop Frye, Anatomy of Criticism, Princeton, Princeton University Press, 1957; reprinted 1990, p. 131-239.

37. No accreditation of the scenario is given on the programme note. In an interview with Mary Leland, Fleischmann states that "Miss Moriarty and I made out the libretto together" and Moriarty goes on to explain that after reading several versions of tale she decided to follow Kinsella's translation (Mary Leland, "The Tain", The Irish Times, 28 September 1981, p. 8).

38. The orchestral work Cuchulainn \& Ferdia - Duel at the Ford (2008) by John Kinsella (b. 1932); the choral work Sétanta (2000) by Eibhlís Farrell (b. 1953); the lament Caoineadh Cu Chulainn (1995) by Bill Whelan (b. 1950); and Deirdre Gribbin's (b. 1967) orchestral piece, Of The Táin (1994).

39. Fleischmann's mother Tilly was born in Ireland to German parents but was performing in Munich and taking piano lessons with Berthold Kellermann, a former pupil of Liszt, when she gave birth to her son on 13 April 1910. In June of that year her husband travelled to Munich to bring his family back to Cork. Although Fleischmann grew up in Cork, the matter of identity was difficult due to his German name and parentage and for almost a decade (1930s), he adopted the pseudonym "Muiris Ó Rónáin", in order to be taken seriously as an Irishman. 


\section{James Wilson's tragic portrayal of the Táin}

Wilson's monodrama, The Táin (1971), was written in collaboration with the music critic and broadcaster, Ian Fox, who chose the saga and adapted it from Kinsella's text. During the 1960s, London-born Wilson's personal circumstances were far from ideal as he was finding it difficult to establish himself as a composer after settling permanently in Dublin at the age of 26 . Wilson was largely self-taught and sought to be seen as a progressive composer in Ireland; he therefore created ways to forge a link with his new homeland. He did this in two ways; firstly his aim was to write a style of music that musicians were eager to perform and therefore he focused on tailoring his music to the technical capabilities of specific performers, and their instruments, in the hope of securing performances of his works. Secondly, he made a conscious effort to embrace the Irish cultural past and composed numerous works that include texts by poets and writers from his adopted country. ${ }^{40}$ Consequently, he was enthusiastic about Fox's choice of text; particularly the relatively recent stature of Kinsella's translation.

Fox's aim was to produce a text in an "archaic style" which corresponded to the translations of the writings within the era of the saga. The opening text does not belong to the actual saga. Fox informed the author that he chose his own words "to set the story the legendary mood in motion" ${ }^{41}$ In keeping with the medieval Irish literature, Fox maintained the topographical element of Kinsella's text which is important for a full appreciation of the Táin. Typically, he adapted the text into narrative passages, which serve to tell the story and set the mood, in anticipation of the poetic lines, which are representative of the various characters portrayed by the solo soprano. The work depicts Queen Medb's destructive journey of greed and jealousy, as it unfolds through a series of alternating recitatives and arias, framed by a prologue and epilogue. Wilson's employment of recitative consistently engages the narrative aspect of Fox's text, and the arias deliver the poetic lines of the various characters. The work is divided into two parts; the first of which captures the harshness of the tale and the second discloses the brutal consequences of Medb's jealousy.

The Táin, scored for solo soprano, piano and percussion was written specifically for the Dublin-born, and internationally renowned, vocalist Veronica Dunne. Wilson sought to "show-off her astonishing vocal range" and described the work as a "one woman opera of his own invention". ${ }^{42}$ The stamina of the solo singer is

40. Irish Songs, Op. 40 (1970) comprise texts by: Thomas Moore ("Music at Night”), George Darley ("Sea Ritual”), Jonathan Swift (“A City Shower"), Charles Lever ("Swallows”, “The Widow Malone”), James Stephens ("A Glass of Beer"), Aubrey Thomas de Vere ("The Black Rose”). Other works include: Upon Silence, Op. 54 (1972) with a text by William Butler Yeats, Songs of Welcome, Op. 70 (1978) with a text by Francis Ledwidge, and Plurabelle, Op. 89 (1982), with a text by James Joyce.

41. Angela Horgan Goff, personal interview with Ian Fox, 29 October 2011. For the complete text of Ian Fox's libretto, see Angela Horgan Goff, Cultural Constructs of National Identity in Irish Saga-Inspired Musical Composition, PhD thesis in musicology, Waterford Institute of Technology, 2014, p. 219-225.

42. Angela Horgan Goff, personal interview with James Wilson, September 1996. The vocal line ranges from $d-a b$ " 
put to the test as the virtuosic role requires her to portray multiple characters, both male and female: scribe, narrator, prophetess, Queen Medb, (her husband) Ailill, Cú Chulainn and Fer Diad. Thus the challenge in The Táin lies in the convincing bringing to life of both the male and the female vocal lines, while simultaneously engaging the audience in the musical narration of an ancient Irish saga. To this end, Wilson's compositional writing features several unifying devices that serve a narrative function and, in turn, inform the technical demands made of the solo soprano.

The most obvious narrative function is the precise accentuation of the text, which allows the singer to narrate musically - a key feature of Wilson's compositional style. The Táin is text-oriented in that the clarity of the words is consistently reinforced by Wilson's syllabic setting, and this is further emphasised by the dominant role of the singer, particularly in the freely-spoken and recitative sections. The inclusion of several speech devices, such as parlando, freely spoken words, and whispering, gives ample scope to the singer to effectively heighten the drama of the work and also provides an opportunity to relax the voice. Despite the length of the work (thirty-five minutes), the singer easily holds the attention of the audience as her narrative role is highlighted by the clarity of the word-setting, thus enabling the listener to focus on the subject-matter of this ancient Irish saga.

Another narrative device is the use of a drone effect in the piano line which is illustrated through the expressive function applied to the interval of a fourth and its complement, the fifth. Its repetitive use implies a sense of a marching army and this may be Wilson's musical answer to the portrayal of the topographical element of the saga as the armies gradually approach from all over Ireland to help Medb secure the Bull. As fourths and fifths feature prominently throughout the composition, their aural implication frequently provides an archaic sound which is in keeping with the temporal origins of the saga.

Despite Wilson's vocal writing being sympathetic to the enunciation of the words, it presents numerous vocal challenges. The singer's virtuosic ability has to bring both the male and female vocal lines to life through the skillful manipulation, and rapid changing, of timbre. The proximity of the contrasting vocal registers, requiring a rapid change of timbre, proves an arduous task for a singer. Perhaps due to the specific vocal requirements, The Táin has only been performed by Veronica Dunne, whose last performance of the work was during Kilkenny Arts Week, 1975. For more than sixty years, the late Veronica Dunne (1927-2021) was an inspiring teacher and key figure who influenced the art of operatic singing in Ireland and abroad.

Wilson's timely engagement with the Táin in 1971 benefited from the success of Thomas Kinsella's translation which had recently brought the saga to prominence in Ireland. His embracing of Irish culture (predominantly through a variety of Irish texts) reveals a connection with Ireland as he sought to create a personal identity and become a composer of note in Irish art music. An exploration of cultural constructs of Irish identity in Wilson's score of The Táin shows that his focus in establishing himself as a composer of note in Ireland, was to write works that were 
propitious to performers and that they predominantly engaged Irish texts. ${ }^{43}$ The clear enunciation of the words in The Táin emphasises his interest in the text, however, the depth of association which he applies to the words appears secondary to his concern to showcase the skills of the performer. ${ }^{44}$ Wilson's main consideration appears to be for the performer(s) of his music and this is evidenced by the fact that he created a "one woman opera" in order to show-off Dunne's "astonishing vocal range". The fact that several of the singers he wrote for remained loyal to him, suggests a collegial element to Wilson's work, which helped him to establish a cultural identity and simultaneously develop his career.

\section{Aloys Fleischmann's heroic portrayal of the Táin}

In contrast to Wilson focusing on the enunciation of the saga, ten years later Fleischmann captured the visual aspect of the literature in the first full-length ballet ever written by an Irish composer, The Táin (1981). Although Fleischmann was born in Germany, he was reared in Ireland, became a fluent Irish speaker, and spent most of his life as an educator who was deeply committed to both the Irish language and Irish traditional music. The Táin (1981) was composed for Joan Denise Moriarty's Irish Ballet Company who performed it at the 1981 Dublin Theatre Festival, a year after Fleischmann's retirement as professor of music, University College Cork (UCC, 1934-1984). Together, both the choreographer, Moriarty, and Fleischmann fashioned a scenario for the ballet from Kinsella's translation and their interpretation adheres to a romantic or heroic plot that features Cú Chulainn as the triumphant protagonist. Moriarty, a woman dedicated to establishing a ballet company against all odds, and Fleischmann shared a similar enthusiasm for the fusion of Irish traditional and contemporary lexica, and subsequently they enjoyed a successful collaboration for almost half a century. ${ }^{45}$ According to the programme note of The Táin, the aim of the scenario is to "conjure up something

43. Despite Wilson's compositional oeuvre displaying an eclectic choice of text, ranging from anonymous to established writers, spanning centuries and nationalities, he continued to maintain a cultural link with Ireland throughout his compositional career. A sample of these include: Robert Burns (1759-1796), Robert Browning (1812-1889), Paul-Marie Verlaine (1844-1896), Gerard Manley Hopkins (1844-1889), Oscar Wilde (1854-1900), William Butler Yeats (1865-1939), James Joyce (1882-1941), Francis Ledwidge (1887-1917), Elsa Gress (1919-1988), Leland Bardwell (1922-2016), Susan Connolly (b. 1956), and Micheal O'Siadhail (b. 1947).

44. These include for example, Veronica Dunne, Jane Manning, Dorothy Dorow, and Peter McBrien.

45. For further reading on Moriarty, see Joan Denise Moriarty: Founder of Irish National Ballet, Ruth Fleischmann (ed.), Dublin, Mercier Press, 1998. For ten years after their meeting, Fleischmann's compositions are mainly ballet or folk dance works for Moriarty's Company. His commitment to the genre of ballet is affirmed by his conscientious efforts as chairman of the Advisory Board of the Cork Ballet Company (1947-1992) and as vice-chairman of the Irish Ballet Company/ Irish National Ballet (1973-1989). The works include Suite The Cake Dance (1957), Bata na bPlanndála [The Planting Stick] (1957), Macha Ruadh [Red Haired Macha] (1955), Tableau for “An Tóstal” III (1953), An Cóitín Dearg [The Red Petticoat] (1951), and The Golden Bell of Ko (1947). 
of this stark, remote world while following the main outlines of the story". ${ }^{46}$ In this sense Moriarty and Fleischmann were trying to bring their "remote world" to a wider audience and portrayed the romantic mythos by defining the contrasting elements of the saga.

The grander scale of a ballet naturally gives ample scope for detail and embellishment and in this case the scenario deviates in two major instances from Kinsella's translation; the emotional peak of the drama is portrayed in the ballet as a heated chess game that ends in violence between Medb and Cú Chulainn rather than the tragic duel between the latter and his foster brother Fer Diad. ${ }^{47}$ The exclusion of the three-day bloody battle at the ford may have been due to practicalities in that it was more feasible to stage a dramatic confrontation between the two main protagonists, thus highlighting their conflicting interests. Secondly, the jester, Tamun, features more prominently in the ballet, whereas he is only briefly mentioned in the Kinsella translation. This may have been to provide some relief as the more prominent role of Tamun's light-hearted foolish nature counteracts the seriousness of Nemain, the goddess of war. The ballet continues to highlight the antithetical elements of the saga by defining the distinctive male and female dances, and by contrasting the greedy warrior couple, Medb and Ailill, with the heroic Cú Chulainn who often shares tender moments with his devoted Emer. ${ }^{48}$ In addition, the contrasting elements of the ballet are instantly visible by means of a huge gauze on stage displaying the Brown Bull of Cooley in a vicious horn-lock with Findbennach, the White Bull. The specificity of the costumes comprises glittering blues and silvers for the Ulstermen and women whereas the Connacht camp wore warm reds and browns. ${ }^{49}$ The costumes and sets were created by Patrick Murray who received the Spencer Freeman Award for his artistic designs in an Irish production. ${ }^{50}$

Fleischmann includes narrative devices in his visual and musical portrayal of the saga. In the "Girls' Dance" (Act I, sc. iv) for example, the female dancers are represented by a pentatonic melody (based on five notes, B b , C, D, E b , F) that operates as a motto-theme throughout the ballet. This theme engages a distinctively Irish idiom and acts as a unifying device throughout the ballet. For the female scenes, Moriarty also engages Irish features as her movement vocabulary combines

46. Aloys Fleischmann, programme note for performance of Ballet Suite: The Táin by the RTÉ Concert Orchestra, 15 October 1982.

47. The idea of a chess game is not novel as it features in Kinsella's translation of the saga when Ailill challenges Fergus to play fidchell (chess).

48. Other works by Fleischmann reference characters from The Táin, including the choral work, Clonmacnoise (c. 1986), based on the poem by Frank O'Connor, in which the first of the eleven episodes is entitled "Ailill the King". Tableau for "An Tóstal” III (1953) depicts various mythological figures in tableau.

49. Carolyn Swift, “The Professional Ballet Companies: Critics”, in Joan Denise Moriarty: Founder of Irish National Ballet, p. 224.

50. Murray's choice of blue and silver for the Ulster dancers is perhaps unusual in that the symbolic colour of Ulster is "red" whereas this is the colour assigned to the costumes for the Connacht Camp. 
ballet with subtle elements of Irish dancing, such as tipping and battery. ${ }^{51}$ The female dances are typical examples of how Fleischmann and Moriarty fuse Irish traditional and contemporary lexica, thus emphasising a visual and aural sense of Irish identity in the reconstruction of an ancient tale from their literary heritage.

These exclusively local features would resonate with a contemporary audience, as both Irish dancing and traditional music are key features of the national school curriculum (predominantly through singing and learning the tin whistle) ${ }^{52}$ and therefore they have been embedded in Irish consciousness. In addition, and looking further afield, perhaps due to the Irish diaspora and the international success of Riverdance, ${ }^{53}$ the distinctiveness of both Irish traditional music and dance is recognisable across the globe and therefore these features would be recognisable in a current performance of The Táin. Although one cannot account for the lacuna of the viewer / listener, it is doubtful that the geographic locale of this ballet could be called into question in the English-speaking Western world.

Similar to Wilson, who adhered to traditional idioms from the European canon (tonal compositional language and an aria and recitative structure), Fleischman employed a tonal vocabulary. In contrast however, Fleischmann's distinct relationship with Irish traditions clearly informs his approach as his musical language produces a romantic soundscape infused, at times, with idioms from the Irish traditional repertoire. In an attempt to sound more "modern" Fleischman ventured to incorporate both aleatoric and 12-tone techniques, ${ }^{54}$ albeit briefly, in The Táin. He believed that because the general style of the music in The Táin was "traditional" (meaning tonal), it would "hardly find favour with the critics, professional or lay". 55 What was increasingly coming to the fore in Irish art music, during the 1970s and 1980s, was a striking plurality of consciousness and in some respects this was a repudiation of things Irish.

51. David Wallace, "Aloys Fleischmann and Joan Denise Moriarty: The Music and the Dance: A Choreomusical Analysis of the 'Camp Maiden's Dance' from The Táin”, conference paper: The First International Conference of Irish Music and Musicians, Durham University, 14 July 2010.

52. These key features are embedded in the Irish Primary School Curriculum/Curaclam na Bunscoile, and can be utilised by individual teachers at their own discretion.

53. Riverdance was written by the Irish composer, Bill Whelan, and was first performed as the interval act of the Eurovision Song Contest hosted in Dublin, in 1994. The music went straight to number one in the Irish charts and entered the top ten in the United Kingdom. Riverdance was subsequently developed into a full-length show and has been performed across the globe to phenomenal acclaim thus becoming a symbol of Irish culture.

54. Aleatoric music requires elements of the composition to be left to chance and therefore the performers / conductor have a certain amount of freedom which results in varied outcomes. 12-tone music is where the 12 chromatic notes of an octave are of equal importance to each other and are given a particular order for each composition. Hence the term, 12-tone, is the opposite to the more traditional form of tonal music which is expressed in a key (or a variety of keys that relate to each other). 12-tone serialism, in addition to the ordering of the 12 pitches, includes other musical elements, such as series of rhythms and dynamics. Fleischmann's music does not adhere to a strict use of 12 -tone serialism.

55. Aloys Fleischmann, “On Writing Music for Ballet”, Soundpost, no. 4, 1981, p. 11. 
Testament that The Táin was a worthwhile cultural experience for Irish audiences is the fact that the ballet was performed to full-houses at the Gaiety Theatre, Dublin, and completed a successful week-long production in 1981. The ballet has not been performed since 1981; this is perhaps due to the collapse of the Irish Ballet Company in 1991 in light of Joan Denise Moriarty's ill-health and her subsequent death in January 1992. Fleischmann's concert works, extracted from The Táin, have since been performed. ${ }^{56}$

National consciousness and a strong sense of Irish identity proved to be a highly productive source of inspiration for Fleischmann's music. His quotient of Irish folk idioms in The Táin does not necessarily constitute a sense of nationalism in itself, rather it is the use to which such material is put that manifests the ideology. The fact that the background characters of the ballet were peasants, and therefore emblematic of a folk idiom, symbolises both an essentialist and realistic image of Ireland. The effect of this iconicity results in a cultural construction of national identity as opposed to the idiom being merely employed as an exotic decoration. This iconicity illustrates Fleischmann's skill in being able to both present and comment on the drama simultaneously. The fact that folk idioms are often felt in his music suggests that they are as deeply rooted and valid an experience as art music. This serves to elevate the music of the people to a more sophisticated level and provides an opportunity for social cohesion. This is reinforced by the fact that the music comprises the more traditional practice of a romantic (tonal) language favoured by audiences.

\section{Conclusion}

The appeal of the ancient Irish saga, the Táin, is its universality and perhaps its timeless journey through the centuries in that its themes are still relevant today. Despite the Irish cultural connections in the two Táin-inspired works by Wilson and Fleischmann, the main difference is that Wilson's engagement with the saga serves as a conjugate to displaying Veronica Dunne's virtuosic vocal skills, whereas Fleischmann's concern appears to be reception and public meaning in that he strives to immerse the audience in a deep-rooted cultural experience. Fleischmann's loyalty is to his traditionalist outlook as his attitudinal response to the Táin reflects lingering influences of nationalism. The fact that Wilson does not employ idioms from the Irish traditional repertoire does not refute his desire to forge a cultural link with Ireland. Wilson's enthusiasm for his librettist's choice of text is reflected in his style of writing which is sympathetic to the clear enunciation of the words and therefore results in an effective, albeit conservative, musical narration of the

56. For example: Ballet Suite: The Táin (1982) premiered 15 October 1982 by the RTÉ Concert Orchestra at the National Concert Hall, Dublin; and Five Dances from The Táin was first performed 8 March 1991 by the National Symphony Orchestra of Ireland at the National Concert Hall, Dublin. The score for the latter performance comprised photocopies from the original ballet manuscript. 
saga. Within a pluralistic Irish culture, Wilson and Fleischmann have created individual identities, contributed to the cultivation of a tradition of Irish art music and forged a link with the established literary tradition. In engaging with Kinsella's literary re-creation of the saga, both Fleischmann and Wilson have become part of the continuing artistic process that engages with the ancient world of the Táin Bó Cuailnge.

One can argue as to whether the Kinsella/le Brocquy re-interpretation of the Táin led to a new era of Irish cultural nationalism. What is certain is that, at the time of publication (1969), this collaboration between poet and painter infused an unexpected energy that enticed other creative artists to the saga. The transnational dimensions and cultural resonance of the Táin are evident in the creative works discussed. The attraction may have manifest, for example, from artists favouring an alternative anti-establishment / Catholic aesthetic or as a reaction against youth culture which was gaining huge momentum in the English-speaking Western world. The irony here is that one of the main characters from the Táin, Cú Chulainn, has become part of the popular youth culture.

The collective energy of these artists focusing on the Táin in turn inspired other creative artists (and national institutions) to invoke ancient Irish themes during the 1970 s and 1980s. This counterculture, or sense of nostalgia, is shaped by cultural traditions (ancient sagas, designs and Irish musical idioms) and therefore places Irish identity to the fore. These works incorporate modernist ideas as they fuse European techniques with ancient Irish themes and therefore reflect lingering influences of nationalism. While the evoking of the past may have been the dawning of a new chapter in Irish cultural nationalism, it can also be seen as artists striving to create an aura of permanence and continuity in an otherwise fractured sovereign history.

Angela Horgan GofF

Independent scholar 